Check for updates

AUTHOR:

Amani Saidi ${ }^{\top}$

\section{AFFILIATION:}

1Director: Quality Assurance \& Promotion Coordination, Office of the Chief Executive Officer, Council on Higher Education, Pretoria, South Africa

\section{CORRESPONDENCE TO:} Amani Saidi

\section{EMAIL:}

Saidi.A@che.ac.za

\section{HOW TO CITE:}

Saidi A. Commentary on the 2019

Quality Promotion Conference

organised by the Council on

Higher Education. S Afr J Sci.

2019:115(11/12), Art \#7484

1 page. https://doi.org/10.17159/

sajs.2019/7484

ARTICLE INCLUDES:

$\square$ Peer review

$\square$ Supplementary material

\section{KEYWORDS:}

academic integrity, higher education research, publication, teaching and assessment

\section{PUBLISHED:}

27 November 2019

\title{
Commentary on the 2019 Quality Promotion Conference organised by the Council on Higher Education
}

As part of its quality promotion initiatives, the Council on Higher Education (CHE) organised a conference themed 'Promoting Academic Integrity in Higher Education', which took place from 26 to 28 February 2019 at the International Convention Centre of the Council for Scientific and Industrial Research (CSIR) in Pretoria, South Africa.

The aim of the conference was to provide a platform for sharing experiences and lessons on, and good practices for, combating acts of academic dishonesty, as well as for raising issues and stimulating dialogue on the need to maintain academic integrity throughout the higher education value chain across the higher education sector. As an outcome of the conference, it was expected that the participants would commit themselves to ensuring that the credibility and global competitiveness of higher education in South Africa would not be allowed to be compromised.

The 200 participants were mostly from South Africa, but there was also a sizeable contingent from seven other African countries: Botswana, Malawi, Seychelles, Tanzania, Uganda, Zambia and Zimbabwe. The participants were from public and private higher education institutions, quality assurance agencies or councils, statutory and non-statutory professional bodies or councils, and government departments or ministries responsible for higher education in the different countries.

The structure of the conferences included a discussion of a panel of experts on academic integrity, keynote addresses in plenary sessions, and parallel paper presentation sessions. The papers covered different conference sub-themes including discourses on academic integrity and quality; academic integrity in teaching and learning, curriculum design and review, assessment and certification, and research and publishing; threats to academic integrity and their impacts; institutional systems and services for promoting academic integrity; and leveraging technology for the promotion of academic integrity. In total, there were 36 paper presentations, including the 4 by the keynote speakers which were presented during the plenary sessions.

The formal feedback received from the participants indicated that the conference was a resounding success. Participants spoke with one voice in condemning acts of academic dishonesty in higher education institutions. They issued a clarion call for all role players in higher education to have their hands on deck in the efforts to uproot all forms of academic dishonesty and to promote academic integrity.

Of the papers from the conference subsequently submitted and accepted for publication in this themed issue of the South African Journal of Science (SAJS), one is on the contentious topic of cheating in examinations, which generated much interest and debate among participants at the conference. Using examples from different parts of the world, the paper documents the prevalence and risks of the cheating that takes place in examination venues.

The second paper is on the long-standing debate on whether it is possible to maintain high academic standards and integrity when there is 'massification' in higher education, understanding that 'massification' often results in abnormal lecture-to-student ratios, and the inability to ensure that all students have sufficient access to teaching and learning facilities. The paper contends that academics have to learn from their experiences in order to continuously improve their teaching and assessment methods so that their standards and integrity are not compromised by factors associated with large classes.

The conference also opened a lid on the malfeasance of illicit sexual relationships between students and lecturers. From the comments on the conference papers that focused on this topic, it was clear that this issue is a huge threat to academic integrity and one whose increasing prevalence should be a concern for all. One aspect of this issue is the so-called 'sexually transmitted marks' phenomenon, and the conference paper that explored the prevalence of this phenomenon is also published in this themed issue. The paper recommends the development, adoption and enforcement of institutional policies aimed at controlling this phenomenon from both source points - students and lecturers.

The last paper makes a case for external quality assurance agencies such as the CHE to take on the responsibility of promoting academic integrity as a foundation for quality teaching and learning, research, and engaged scholarship. It presents a 'higher education ecosystem approach' which it recommends for adoption in order to ensure that maintaining academic integrity is the business of everyone that forms part of the 'higher education ecosystem'.

The CHE wishes to express its sincere gratitude to the authors of the conference papers that were accepted for publication in the SAJS for the efforts they put into reworking and refining their respective conference papers into papers publishable in a highly reputable journal such as the SAJS.

The CHE also thanks the Academy of Science of South Africa (ASSAf), the publisher of the SAJS, for recognising the significance of the theme of the 2019 Quality Promotion Conference of the CHE, and thereby agreeing to partner with the $\mathrm{CHE}$ in a project to ensure that selected papers from the conference were seen into final publication.

Lastly, the CHE acknowledges the work of the Editor-in-Chief and Associate Editors of the SAJS in continuing to uphold the high standards of quality and integrity of the Journal. 